\title{
Pendidikan Ekonomi Informal Masyarakat Adat Loona
}

\author{
Alfridus Mau Manek ${ }^{1}$, Agung Haryono ${ }^{1}$, Hari Wahyono ${ }^{1}$ \\ ${ }^{1}$ Pendidikan Ekonomi-Universitas Negeri Malang
}

\begin{tabular}{l}
\hline \hline INFO ARTIKEL \\
\hline Riwayat Artikel: \\
Diterima: $13-06-2019$ \\
Disetujui: $20-01-2020$ \\
\hline
\end{tabular}

\section{Kata kunci:}

informal economic education; culture value; indigenous people of Loona; pendidikan ekonomi informal; nilai budaya;

masyarakat adat Loona

\section{Alamat Korespondensi:}

Alfridus Mau Manek

Pendidikan Ekonomi

Universitas Negeri Malang

Jalan Semarang 5 Malang

E-mail: maumanek99@gmail.com

\section{ABSTRAK}

Abstract: Education is a necessity that must be owned by everyone both individually and in groups and society at large. Education can be obtained from formal channels, besides education also arises from knowledge based on experience that comes from interaction with nature and the social environment. Economic education in the family holds an irreplaceable position with existing learning at school because the learning process in the family will occur consciously or not and continue to be given by parents to children about various matters related to household and social activities. In this study, the author wants to explain the process of informal education in the culture of the Loona Indigenous People which is carried out as a process of transferring cultural values concerning attitudes and morals to the younger generation.

\begin{abstract}
Abstrak: Pendidikan merupakan suatu keharusan yang wajib dimiliki oleh semua orang baik secara individu maupun kelompok dan masyarakat secara luas. Pendidikan dapat diperoleh dari jalur formal. Selain itu, pendidikan juga muncul dari pengetahuan berdasarkan pengalaman yang hadir dari interaksi dengan alam dan lingkungan sosial Pendidikan ekonomi dalam keluarga memegang posisi yang tak tergantikan dengan pembelajaran yang ada di sekolah karena proses pembelajaran dalam keluarga akan terjadi secara disadari atau tidak dan berlangsung terus menerus yang diberikan orangtua kepada anak tentang berbagai hal yang terkait dengan aktivitas rumah tangga dan sosial. Dalam penelitian ini penulis ingin memaparkan proses pendidikan informal dalam budaya Masyarakat Adat Loona yang dilakukan sebagai proses transfer nilai budaya yang menyangkut sikap dan moral kepada generasi muda.
\end{abstract}

Segala tindakan ekonomi yang ada pada suatu masyarakat merupakan hasil dari pendidikan yang terdapat pada anggota masyarakatnya. Pendidikan merupakan suatu keharusan yang wajib dimiliki oleh semua orang baik secara individu maupun kelompok dan masyarakat secara luas. Pendidikan tidak semata-mata diperoleh dari jalur formal, melainkan pendidikan juga muncul dari pengetahuan berdasarkan pengalaman yang hadir dari interaksi dengan alam dan lingkungan sosial. Menurut Farecha \& Ilyas (2015) pendidikan keluarga merupakan pendidikan informal di mana dalam penyelenggaraannya, pendidikan keluarga tidak sekedar berperan sebagai pelaksana yang bersifat rutin dan ilmiah, melainkan berperan sebagai pengelola yang bertanggung jawab dalam meletakkan dasar dan arah serta pola kehidupan anak. Begitu pula orangtua, mempunyai fungsi dan peranan dalam proses pendidikan keluarga yang menjadi bagian dari pendidikan informal. Singh (2015) menjelaskan bahwa pembelajaran informal adalah pembelajaran yang terjadi dalam kehidupan sehari-hari, dalam kelaurga, dalam tempat kerja di komunitas tertentu dan melalui minat dan aktivitas individu. Pada konteks ini pengalaman belajar informal lebih berfokus pada proses belajar yang diperoleh dari pengalaman. Oleh sebab itu, sesuatu yang dipelajari secara formal sangat dipengaruhi oleh sesuatu yang dipelajari secara informal begitu juga sebaliknya.

Heger (1998) menyatakan pembelajaran dalam ranah informal perlu mendapat perhatian yang sangat serius dengan menitikberatkan pada empat aspek pembelajaran informal, yaitu (a) pengakuan pembelajaran informal sebagai kredit atas kualitas dan kualifikasi pendidikan formal, (b) pengakuan oleh pendidik dari jenis pendidikan nontradisional, (c) pengakuan oleh peserta didik sejuah mana pembelajaran informal mereka, dan (d) pengakuan terhadap kepekaan pembelajaran informal yang tinggi terhadap faktor-faktor kontekstual. Sumber pendidikan yang paling pertama dan terutama lahir dari dalam rumah tangga atau keluarga, sebab keluarga merupakan suatu kelompok terkecil dalam konteks sosial dan memiliki kedekatan emosional yang sangat erat antara setiap anggotanya, dimana terjadi proses transfer pendidikan dari orangtua kepada anak baik pengetahuan yang bersifat umum maupun penanaman nilai-nilai sikap terhadap setiap individu dalam keluarga yang berlangsung secara berkelanjutan. 
Dengan adanya perkembangan teknologi pembelajaran informal dapat berlasung secara tatap muka dan secara virtual memanfaatkan internet sebagai media. Menurut Pozgaj (2008) terdapat tiga jenis pembelajaran informal yang bersifat tatap muka (1) Temporary learning system; dimana sekelompok orang dibawa dalam jangka waktu tertentu untuk mempelajari topik tertentu, (2) Communities of practice dalam artian tempat orang berbagi kepentingan pribadi atau professional bertemu bersama untuk bertukar pengetahuan dan berbagi sumber daya, dan (3) Learning networks merupakan tempat organisasi dan lintas grup difokuskan pada berbagai pengetahuan dalam masalah yang spesifik misalnya bisnis. Namun, pendidikan informal merupakan sebuah proses belajar yang didasarkan pada percakapan, interaksi sosial, dan kelompok atau komunitas masyarakat sebagai proses pembelajaran yang menjadi bagian dari interaksi antar manusia. Suryani (2017) menyatakan bahwa pendidikan informal dapat berlangsung secara tidak terstruktur, tidak terdapat tingkatan secara kronologis dan bersifat nonkrendensials. Pendidikan informal lebih bersifat pengalaman berlajar yang mandiri dan terjadi bukan karena interasi belajar mengajar buatan, hal ini yang membedakannya dengan pendidikan formal dan nonformal.

Sarwono (2015) mengemukakan bahwa remaja adalah masa transisi dari periode anak ke dewasa. Pada diri remaja, proses perubahan karena pengalaman dan usia merupakan hal yang harus terjadi dalam proses pematangan kepribadiaannya, remaja sedikit demi sedikit memunculkan ke permukaan sifat-sifatnya yang sebenarnya dan harus berbenturan dengan ransangan-ransangan dariluar. Oleh karena itu, pada masa ini lingkungan dari luar sudah mulai memengaruhi tumbuh kembang anak. Pendidikan dapat bersumber dari lingkungan sosial dalam konteks kelompok di wilayah tertentu, seperti kebudayaan atau adat istiadat yang ada pada masyarakat. Sebagai contoh di dalam kehidupan masyarakat di Kabupaten Belu, Propinsi Nusa Tenggara Timur yang mewajibkan seorang laki-laki harus mampu menanggung sebagian mahar seorang gadis sendiri tanpa bantuan keluarga agar disetujui oleh keluarga untuk menikah dan diakui sebagai seorang laki-laki yang jantan atau telah siap membangun keluarga sendiri. Pendidikan ini merupakan sebuah tradisi yang ditanamkan secara turun temurun dan berlaku untuk setiap anggota masyarakat. Dalam konteks ini pendidikan tidak sekedar tentang berbagi pengetahuan melainkan juga penanaman nilai-nilai budaya untuk membentuk moral dan sikap dalam kehidupan di lingkungan dan sosial. Hasan (2018) menyatakan keluarga diharapkan mampu membentuk pribadi anak yang dapat hidup di tengah-tengah masyarakatnya, sekaligus dapat menerima, menerapkan, dan mewarisi nilai-nilai budaya dalam masyarakatnya.

Pendidikan dalam keluarga dan lingkungan sosial, tidak terlepas didalamnya adalah pendidikan ekonomi. Secara formal berdasarkan pengelompokan akademik pendidikan ekonomi merupakan cabang dari ilmu sosial yang mempelajari tentang bagaimana setiap individu memenuhi kebutuhan hidup sehari-hari melalui aktivitas ekonomi yaitu produksi, distribusi dan konsumsi. Pendidikan ekonomi pada jenjang formal mengajarkan bagaimana manusia menjadi pelaku ekonomi yang mampu memiliki sikap rasionality atau rasional ekonomi. Menurut Wahyono (2001) dengan pendidikan ekonomi yang secara intens dalam lingkungan keluarga, akan membentuk manusia ekonomi (homo economicus) yang produktif dan ekonomis dalam pemanfaatan uang maupun sumberdaya lainnya. Keluarga dapat dibentuk sikap yang diperlukan, agar anak kelak setelah mereka dewasa dan menjadi kepala keluarga memiliki ekonomi yang efektif dan efisien. Jelas bahwa pemahaman atas aktivitas produktif dan konsumtif kepala keluarga, bagi kepentingan pengembangan sikap yang dapat mendorong pencapaian efektivitas dan efesiensi atas aktivitas tersebut, dapat dilakukan melalui pendidikan ekonomi di lingkungan keluarga secara intens. Sementara itu, pendidikan ekonomi yang ada pada suatu keluarga atau kelompok masyarakat belum tentu demikian, Koch (2014) menyatakan bahwa tingkatan atau jenjang pendidikan tidak selalu memengaruhi perkembangan pendidikan ekonomi manusia dalam membentuk soft skill melainkan lingkungan pendidikan, keluarga dan teman-teman sebaya juga turut andil.

Pendidikan ekonomi dalam keluarga memegang posisi yang tak tergantikan dengan pembelajaran yang ada disekolah karena proses pembelajaran dalam keluarga akan terjadi secara disadari atau tidak dan berlangsung terus menerus yang di berikan orangtua kepada anak tentang berbagai hal yang terkait dengan aktivitas rumah tangga dan sosial. Menurut Wahyono (2001) pendidikan ekonomi di lingkungan keluarga memiliki kontibusi penting dalam menanamkan perilaku altruistic atau selfish karena keluarga merupakan tempat yang utama bagi setiap individu atau anak dalam bersosialisasi membentukan karakter, sikap, dan nilai-nilai moral yang lahir dari interakasi antar anggota keluarga. Peran penting keluarga dalam pendidikan ekonomi juga ditegaskan Hasan (2018) keluarga yang merencanakan transfer pengetahuan secara terencana memiliki skema yang sistematis dan memiliki tahapan yang jelas. Orangtua merencanakan kapan proses transfer tersebut dimulai dan tahapantahapan yang harus dilalui oleh penerus. Namun sebaliknya, orangtua yang tidak merencanakan proses transfer pengetahuan tidak memiliki tahapan dan waktu yang jelas dalam proses transfer pengetahuan.

Perilaku ekonomi manusia dapat dibentuk dengan adanya proses pembelajaran yang diperoleh dari setiap sektor pendidikan dalam upaya mencerdaskan kehidupan ekonomi manusia dan mendorong terwujudnya suatu kesejahteraan ekonomi masayarakat secara umum. Menurut Setiaji (2014) pendidikan ekonomi informal dapat berlangsung dalam kehidupan rumah tangga keluarga, dalam hal ini bukan hanya tentang permasalahan ekonomi secara teori tetapi realita dalam kaitan dengan interaksi dalam ekosistem. Dengan demikian, bahwa proses pendidikan ekonomi tidak hanya terbatas pada pemenuhan kebutuhan tetapi juga mencakup dimensi lingkungan dan sosial.

Kehidupan dalam keluarga di masyarakat adat Loona masih mempertimbangkan banyak aspek sosial, seperti persaudaraan, kolektivitas, tenggang rasa, dan tolong menolong. Hal ini memilik kemiripan dengan hasil penelitian Basri; dkk (2016) mengungkapkan bahwa dalam kehidupan masyarakat Melayu Kubu Raya mereka terbiasa membagikan hasil panen atau melaut kepada sanak keluarga dan tetangga yang berkekurangan untuk mempererat tali silaturrami. Tentu perilaku yang positif ini lahir dari rasa peduli antar sesama. Masyarakat adat Loona memandang peran pendidikan sebagai simpul-simpul norma dan 
nilai dapat ditegakkan, jika masing-masing pribadi mematuhi tata aturan dalam kehidupannya, melaksanakan norma-norma dalam masyarakat, dan memperbaiki pemahaman landasan yang benar. Inilah tugas yang harus dipikul bersama oleh semua komponen masyarakat. Dalam penelitian ini penulis ingin memaparkan proses pendidikan ekonomi informal dalam budaya masyarakat adat Loona yang dilakukan sebagai proses transfer nilai budaya yang menyangkut sikap dan moral kepada generasi muda.

\section{METODE}

Penelitian ini adalah penelitian kualitatif dengan pendekatan etnografi. Etnografi didasarkan pada asumsi bahwa penengetahuan dari semua kebudayaan memiliki nilai yang sangat tinggi. Djamal (2015) menyatakan makna etnografi adalah untuk membangun suatu pengertian yang sistematik menegenai semua kebudayaan manusia dari perspektif orang yang telah mempelajari kebudayaan tersebut. Sebagai bagian dari proses etnografi memerlukan pengamatan yang luas dan mendalam terhadap suatu kelompok melalui pengamatan partisipan sehingga keterlibatan langsung peneliti sangat penting.

Lokasi penelitian ini adalah masyarakat adat Loona di Kecamatan Lamaknen Selatan, Kabupaten Belu Nusa Tenggara Timur. Sumber data dalam penelitian ini, yaitu sesepuh adat, ketua suku serta peristiwa dan situasi masayarakat sebagai bagian dari penelitian ini. Pengumpulan data mengunakan indept interview atau wawancara mendalam untuk memperoleh data mendasar dan spesifik. Untuk mengelolah data agar lebih bermakna dan mudah dipahami maka analisis data yang dipakai dalam penelitian ini adalah model Miles dan Hubermen (1994) meliputi tahap koleksi data, reduksi data, display data, penarikan kesimpulan, dan verifikasi data.

\section{HASIL}

Masyarakat adat Loona menyadari nilai-nilai budaya dan adat istiadat yang ada perlu untuk diwariskan kegenerasi muda. Untuk itu perlu adanya transfer nilai-nilai budaya kepada anak-anak dan orang muda agar tetap lestari. Selian lestari sikap dan perilaku mereka juga perlu untuk dibentuk sejak dini. Masyarakat adat Loona secara ekonomi rata-rata penduduk hanya bekerja sebagai petani dengan penghasilan yang rendah sehingga salah satu cara anak-anak harus diajarkan untuk bertanggung jawab dan bekerja keras seperti orangtua mereka. masyarakat disana juga sadar bahwa pengetahuan mengenai adat istiadat yang ada di kenaian loona tidak diperoleh dari pendidikan formal atau sekolah sehingga tanggung jawab orangtua dan ketua suku menjadi penting untuk mentrasferkan nilai-nilai budaya itu.

Anak-anak dilibatkan langsung dalam aktivitas ekonomi masyarakat, dalam bertani anak-anak dan genarasi muda dalam masyrakat adat loona di ajak berpartisipasi langsung di kebun, walau peran mereka tak banyak membantu para orangtua hanya berusaha mengenalkan kepada mereka tentang budaya bergotong royong yang kenal dengan istilah kawak atau gowol. Selain anak-anak dilibatkan dalam menganyam atau menenun ketika orangtua mereka melakukannya. Budaya tita mita atau duduk kumpul dalam masyarakat adat Loona dimanfaat sebagian momen transfer nilai budaya melalui pembinaan pengarahan dari para oangtua maupun ketua rumah suku atau klan. Proses pendidikan informal yang ada dalam keseharian Masyarakat Adat Loona melalui proses pembiasaan dan pemberian tanggungjawab. Tujuan agar anak-anak terbiasa dengan bekerja keras sehingga kelak mereka dapat mandiri dan membangun kehidupan yang lebih sejahtera tanpa mengurangi atau mendegradasi nilai-nilai budaya mereka sendiri.

\section{PEMBAHASAN}

Secara disadari atau ditidak nilai-nilai kepedulian dalam budaya masyarakat yang menyangkut aspek sosial maupun ekonomi kepada satu sama lain dalam kehidupan masyarakat adat Loona tidak lepas dari sebuah proses pendidikan yang telah terjadi dalam masyarakat adat Loona baik melalui proses pemberian keteladanan atau kebiasaan yang dilakukan oleh orangtua maupun ketua rumah suku atau klan yang ada. Menurut Ayuningtyas (2014) lingkup keluarga merupakan pendidikan informal yang dilakukan keluarga berbentuk kegiatan belajar mandiri yang dilakukan orangtua kepada anak. Dalam hal ini orangtua memegang peran pentig untuk menanamkan akhlak mulia, sikap keteladanan sebagai bentuk keterampilan hidup.

Pendidikan ekonomi dalam klan atau rumah suku dalam masyarakat adat Loona memegang peran yang sangat penting dalam pembentukan perilaku ekonomi anak karena pembelajaran dalam keluarga akan terjadi secara terus menerus dan secara sadar maupun tidak sadar yang diberikan oleh orangtua kepada anak tentang berbagai hal yang berkiatan dengan aktivitas ekonomi dan sosial. Koch (2014) menyatakan jenjang pendidikan tidak selalu memengaruhi perkembangan pendidikan ekonomi manusia dalam membentuk soft skill melainkan lingkungan pendidikan, keluarga dan teman sebaya juga turut andil. Wahyono (2001) menegaskan pendidikan ekonomi keluarga memiliki peran penting dalam menanamkan perilaku altruistic atau selfish karena keluarga merupakan tempat utama individu dalam bersosialisasi membentuk karakter, sikap, dan nilai-nilai moral yang lahir dari interaksi antara anggota keluarga. Dengan demikian, proses pendidikan ekonomi dalam keluarga penting untuk membangun keteladanan dan sikap anak yang diberikan orangtua dari intensitas komunikasi dalam kehidupan keluarga.

Proses pendidikan yang ada bukan hanya terjadi karena paksaan, melainkan tanggungjawab dan rasa kepedulian terhadap budaya mereka agar terus belansung dan bertahan hingga sekarang. Selain itu, proses pendidikan yang terjadi disana berlangsung dengan melibat anak-anak dan orang muda secara langsung dalam berbagai kegiatan adat, maupun kerjasama seperti kawak dan gowol dalam kehidupan sehari-hari. Setiap kali ada urusan adat dalam salah satu klan atau rumah suku yang 
adat di kenaian Loona, selalu melakukan tita mi atau duduk kumpul sebelum kegiatan adat tersebut dimulai guna melakukan persiapan-persiapan serta meninjau kesiapan anggota klan atau rumah suku untuk menghadapi kegiatan adat yang akan datang. Dalam acara tita mit biasanya pembahasan mengenai urusan-urusan Adat dan kesiapan mengahadapi adatnya yang didahulukan dengan melibatkan orangtua. Setelah itu para pemuda dan anak dikumpulkan untuk melakukan proses pembinaan baik yang masih menempuh pendidikan atau sudah selesai pendidikan formal tetap duduk dan mendengar arahan atau nasehat dari paman atau ketua suku.

Dalam proses pembinaan cenderung menekan pada nilai-nilai budaya yang ada di kenain Loona, seperti cara berperilaku harus sesuai aturan adat yang berlaku. Dalam tahapan pembinaan ini juga ketua suku mendengar keluhan-keluhan dari orangtua tentang sikap anak kandung mereka dalam keseharian mereka di rumah. Anak yang bandel, keras kepala dan pembangkang akan dijadikan topik dan paling disorot dalam proses pembinaan tersebut. Tujannya agar anak tersebut memiliki rasa hormat dan taat kepada orangtua dan menyadari kesalahanya sehingga dapat menjadi lebih baik.

Proses pembinaan kepada generasi muda dalam klan atau rumah suku dikenaian Loona selalu menyangkut sikap sopan santun dan kerja keras khususnya bagi pemuda bila ingin menikah sebagai bekal mengadapi rumah tangga baru, hal penting lainya yaitu menerangkan bagaimana asal usul setiap klan kepada anggota klan atau rumah suku, mengingatkan hubungan ikatan dengan klan lain agar dalam pergaulan sehari-hari tidak saling menyakiti atau merugikan, tetapi harus mengingat dan mengakui ikatan keluarga melalui hubungan antar klan atau rumah suku tersebut.

Ukon atau aturan adat yang berlaku di Kenaian Loona selalu diingatkan terus-menerus kepada anak-anak dan orangtua agar tidak ada anggota suku yang melanggar. Apabila ada anak-anak yang melanggar maka Ukon yang ada khususnya untuk lingkungan hidup, pihak yang paling disalahkan adalah paman atau om dan orangtua karena dianggap tidak bertanggung jawab untuk mendidik anak-anak mereka.

Dalam kesehariannya anak-anak dan orang muda selalu diajak untuk berpartisipasi dalam kegiatan-kegiatan kawak yang dilaksanakan di kebun. Walaupun tenaga mereka tidak banyak membantu tetapi tujuan anak-anak diajak untuk mengenalkan kegiatan kawak sejak dini dan terbiasa dengan bekerja kebun. ketika ada acara adat, anak-anak dan orang muda selalu diberikan tugas untuk mempersiapkan air minum dan mencari kayu bakar. Selain itu, pada saat menjelang pengantaran belis perempuan biasanya para remaja dan anak muda ditemani beberapa orangtua diutus untuk pergi bekerja di rumah pihak laki-laki guna melayani keluarga pihak laki-laki yang sedang berkumpul. Melayani dalam artian menyiapkan konsumsi, atau lebih dikenal dengan istilah tase/tawaka dan talama.

Terdapat ungkapan yang sering disebut oleh ketua suku atau para orangtua kepada generasi mudanya yang berbunyi $e i$ roe iskola legul na matenek ow, adat na bei mil gua bu ei nei no tara lesin ni homosi ei musti nei niol mak homo si le hilere ei tara rol o riwal mil gege rale gie. Ungkapan ini berari bahwa setinggi-tingginya kamu sekolah dan menjadi pintar sekalipun, pengetahuan kamu tentang adat yang diwariskan nenek moyang tidak bisa melebihi kami sehingga kamu perlu mendengar kami agar kelak kamu dapat meneruskannya kepada anak dan ponakan kalian. Masyarakat adat Loona percaya bahwa pendidikan mengenai adat istiadat disana tidak diperoleh dari pendidikan formal sehingga peran orangtua dan ketua suku kepada generasi muda menjadi sangat penting dalam penanaman nilai-nilai budaya yang ada. Tujuannya sederhana yaitu membentuk sikap perilaku generasi agar selalu sejalan dengan budaya warisan nenek moyang yang harus terus dijaga dan dilestarikan.

\section{SIMPULAN}

Impilikasi pendidikan ekonomi informal dalam budaya masyarakat adat Loona terjadi melalui proses pembiasaan kepada generasi muda dengan melibatkan mereka dalam berbagai kegiatan dan diberikan tanggungjawab berupa pekerjaan yang bersifat ringan. Kemudian transfer nilai budaya dilakukan oleh ketua suku atau paman sebagai bentuk tanggungjawab terhadap generasi muda atau penerus klan agar budaya tidak hilang, taat terhadap aturan adat dan menjadi pekerja keras. Temuan dalam penelitian masih sangat bersifat umum karena ini adalah penelitian pertama. Selanjutnya, perlu adanya pengembangan bahan ajar berbasis budaya lokal di masyarakat adat Loona agar dapat diterapkan pada jenjang pendidikan formal.

\section{DAFTAR RUJUKAN}

Ayuningtyas, T. (2014). Pengaruh Pendidikan Ekonomi di Keluarga, Pembelajaran Ekonomi di Sekolah terhadap Perilaku Konsumsi yang Dimediasi oleh Prestasi Belajar. Tesis tidak diterbitkan. Universitas Negeri Malang, Malang.

Ayuningtyas, T. (2014). Pengaruh Pendidikan Ekonomi di Keluarga, Pembelajaran Ekonomi di Sekolah terhadap Perilaku Konsumsi yang Dimediasi oleh Prestasi Belajar (Studi pada Siswa SMA Negeri Kelas XI IPS Se-Kabupaten

Lumajang). Tesis tidak diterbitkan. Universitas Negeri Malang, Malang.

Basri, M., Djatmika, E. T., Wahyono, H., \& Witjaksono, M. (2016). Caring Economics Dalam Rumah Tangga Masyarakat Melayu Kubu Raya. In National Conference on Economic Education.

Djamal. (2015). Paradigma Penelitian Kualitatif. Yogyakarta: Mitra Pustaka.

Farecha, N. N., \& Ilyas, I. (2015). Pendidikan Kewirausahaan di Lingkungan Keluarga (Studi Empiris di Kelurahan Tingkir Lor Kota Salatiga). Journal of Nonformal Education, 1(1), 61- 68.

Hasan, M. (2018). Pendidikan Ekonomi Informal: Bagaimana Pendidikan Ekonomi Membentuk Pengetahuan pada Bisnis Keluarga? JEKPEND: Jurnal Ekonomi dan Pendidikan, 1(2), 30. https://doi.org/10.26858/jekpend.v1i2.7262 
Hager, P. (2006). Recognition of Informal Learning: Challenges and Issues Recognition of Informal. Journal of Vocational Education \& Training, 50(4), 521-535. https://doi.org/10.1080/13636829800200064

Koch, A. K., Nafziger, J., Suvorov, A., \& van de Ven, J. (2014). Self-Rewards and Personal Motivation. European Economic Review, 68, 151-167. https://doi.org/10.1016/j.euroecorev.2014.03.002

Pozgaj, Z. (2008). Informal Learning in Lifelong Education. International Journal of Emerging Technologies in Learning (IJET), 3, 46-50.

Singh, M. (2016). Global Perspectives on Recognising Non-Formal and Informal Learning: Why Recognition Matters. In International Review of Education, 21(62), 127-129. https://doi.org/10.1007/s11159-016-9534-0

Setiaji, K. (2014). Pendidikan Ekonomi Berwawasan Lingkungan di Universitas Konservasi (Studi Kasus Integrasi Nilai Konservasi di Fakultas Ekonomi Unnes). Prosiding Pluralisme dalam Ekonomi dan Pendidikan (hal. 636-651). Universitas Negeri Semarang, Semarang.

Suryani, I. (2018). Pentingnya Pendidikan Informal tentang Ekonomi pada Keluarga Transmigran. Jurnal Teori dan Praksis Pembelajaran IPS, 2(2), 89-94. https://doi.org/10.17977/um022v2i22017p089

Sarwono, W. S. (2015). Psikologi Remaja. Jakata: Rajawali Pers.

Wahyono, H. (2001). Pengaruh Perilaku Ekonomi Kepala Keluarga terhadap Intensitas Pendidikan Ekonomi di Lingkungan Keluarga. Disertasi tidak diterbitkan. Universitas Negeri Malang, Malang. 